\title{
Application of the Laser Radiation in Patients of Pressure Ulcers: Clinical and Histomorphometric Analysis of the Derm
}

\author{
José Carlos Tatmatsu Rocha ${ }^{1}$, Maria Tereza Jansem de Almeida Catanho ${ }^{2}$ and Diógenes \\ Luís da Mota ${ }^{2 *}$ \\ ${ }^{1}$ Universidade Federal do Piauí, Av. São Sebastião, 2819; 6420220; tatmatsu@ufpi.br; Parnaíba - PI - Brasil. \\ ${ }^{2}$ Universidade Federal de Pernambuco, Av. Professor Moraes Rego, 1235; Cidade Universitária, \\ dilmot@bol.com.br; 50670901;Recife-PE-Brasil
}

\begin{abstract}
In this work, we analyze the clinical alterations and histological modifications in patients with not infect ulcers of pressure, submitted to the Laser irradiation GaAs (wavelength $904 \mathrm{~nm}$, doses $3 \mathrm{~J} / \mathrm{cm}^{2}$, during 1 minute and prompt application) during 5 days consecutive and as a group radiated during 15 days alternating. In the clinical evaluation after the laser irradiation observed presence of exudation, granulation tissue and points of bleed after the third day of irradiation. The computerized morph quantitative analysis demonstrated that submitted to the laser irradiation during the 15 days busy area for the 4115,922 vases was of $\mu^{2}$, and in the radiated ones during 5 4348,253 days of $\mu^{2}$, both in a 0,25 area of $\mathrm{cm}^{2}$ of derma. The gotten results suggest that this therapeutically one was efficient as to assist in the processes of tissue regeneration in the patients treated in the research.
\end{abstract}

Keywords: GaAs laser therapy, pressure ulcers, tissue regeneration, angiogenesis morphometry

\section{INTRODUCTION}

Patients submitted long periods of rest, present pictures of edema, fibrosis and formation of Pressure Ulcers (UP) in points of pressure in the interface skin - bones lumps. In luminous sources the light is produced by the spontaneous emission of the radiation, in which the atoms and molecules are stimulated with energy, generally electric, in such way that the electrons are dislocated for superior orbits of energy. At the moment that such electrons occupy this orbits, suffer instability and fall spontaneously for levels of energy more low and with this energy liberates its extra in form of photons of light, whose energy characteristics will depend on the levels of energy that the excited electron fell, as well as the quantum energy inversely are related to the wave length. As cells and vessels in the organism it has different sensibility for the effect of the radioactive induction, the dose concept accomplishes was used taking in consideration all the cells radiated in detriment with the health (Amaral, 2002).The concept of absorbed dose has some limitations for

${ }^{*}$ Author for correspondence 
evaluating biological effectiveness of exposure to radiation. On the other hand, effective dose was introduced to represent the long-term risk of harm of radiation exposure, in particular the risk of induced cancer by radiation (Amaral, 2002). The stimulated emission of the radiation occurs when an incident photon interacts with an atom that already is excited and its quantum energy must accurately be equal to the difference in the levels of rest and excited of the electron. Angiogenesis is a mechanism that involves a series of stages, culminating, in finishes analyzes, with the formation of hair sprouts that soon after, join themselves for anastomose and give origin to the circulatory chain function (Silva et al., 2007).The objective of this work was to evaluate the action of the Laser of low GaA power when radiated in a series of human patients who present Ulcers of Pressure, using themselves as parameters histological and morphometric analyses.

\section{MATERIALS AND METHODS}

The sample was constituted by 12 cases that presented UP not infects, submitted to the cleanness surgical of the wound and interned in public hospitals of the city of Sao Luís - Brazil. The patients had been separate in two groups, group radiated with Laser during 5 days consecutive and as group B radiated during 15 days alternating. The wounds had been radiated by the laser GaAs diode (Arsenate-Gallium), pulsed, wavelength $904 \mathrm{~nm}$, power of peak of $20 \mathrm{~W}$, and density of 3 prompt radiating energy of $\mathrm{J} / \mathrm{cm}^{2}$. The application method was prompt, dividing it area to be radiated in 2 quadrants of $\mathrm{cm}^{2}$, being the time of application of each quadrant of $1 \mathrm{~min}$. The patients had been clarified in relation to all the stages of procedure and its familiar ones had signed a term of in agreement clarification To seem CNS 196/96.

\section{Clinical analysis}

The wounds had been evaluated clinically, filling protocols in $2^{\text {nd }}$ day of after-debridement for all the patients and, also in the last day of treatment, that is, $5^{\text {th }}$ day in the group and $15^{\text {th }}$ day group $\mathrm{B}$, as much in the place radiated how much in the other extremity of the ulcer (control). The criteria of exclusion for the sampling had been: necrosis fabric presence and/or serosa without possibility of surgical debridement, wounds with high ratio of infection, patients with high risk of imminent death, hemodynamic unstable, not previous the familiar assent and not the assent of the hospital institution in which they were inserted.

\section{Histology}

The biopsies had been carried through in as day of after-debridement and in the last day of irradiation in the two groups and the B. it Was proceeded approximately exeresis from fragments of skin measuring $0,5 \mathrm{~cm}$ of length for $0,5 \mathrm{~cm}$ of width and $0,2 \mathrm{~cm}$ of depth $\left(0,25 \mathrm{~cm}^{2}\right.$ or $\left.2500 \mu \mathrm{m}^{2}\right)$. It was standardized to collect the fragments next to the scarify edges. After the fragments to be removed and duly identified, we carry through the standardized procedures for the assembly of the histological blades. Of the cuts gotten with the thickness of $6 \mu \mathrm{m}$, some had been colored by the hematoxilin-eosin and others for the tricromic of Masson, being the assembly proceeded with synthetic resin.

\section{Morphometric analysis}

The morphometric analysis was carried through using a system of analysis of images computerized, constituted of a microscope to trinocular, provided with connected microcamera the computer and the data analyzed in Software Image Lab (SOFTIUM). Of the 24 gotten blocks: 96 histological preparations (blades) (96 sections to per bloc, were stained with Masson's trichrome and 24 were randomly selected you morphometry) of each block colored by the tricromic of Masson and after that 24 chosen teams randomly. In each preparation, 6 fields had been chosen randomly na analyze parameters: Avs $=$ area vessels, Dmax $=$ maximum diameter vessels, $\mathrm{dmin}=$ minimum diameter vessels.

\section{RESULTS AND DISCUSSION}

In $2^{\text {nd }}$ day of after-debridement, we observe in the two groups, and the isolated $\mathrm{B}$, areas with amorphous tissue, conjunctive tissue underlying with edema and congestion with infiltrated inflammatory composition predominantly for complete and depraved leukocytes and some sanguineous vessels. In the histological preparations, we could mainly analyze the histological evolution of the patients when radiated by GaAs Laser, evaluating itself the increment or not of the number of vessels, the 
formation and disposal of collagen staple fibers and its correlation with the carried through clinical evaluation during the treatment. We notice that the patients radiated with $\mathrm{GaAs}$ laser with doses of 3 $\mathrm{J} / \mathrm{cm}^{2}$, after the treatment, had presented great amount of neoform vases and collagen staple fiber formation, as much in the radiated ones with 5 how much with 15 days, not having significant differences to optic microscopy. Results gotten demonstrate that the busy area for the neoform vessels after the laser irradiation GaAs $(904 \mathrm{~nm})$ presented a average around $4115,922 \mu \mathrm{m}^{2}$, in patients of group B, radiated during 15 days, whereas the group control presented a covering of area for the vessels that were gifts around $1519,758 \mu \mathrm{m}^{2}$, in a total area of $5635,68 \mu \mathrm{m}^{2}$, in a sample of derma of $0,25 \mathrm{~cm}^{2}$. The group the radiated one during 5 days presented resulted similar to group $\mathrm{B}$, not having significant differences, since the area presented for the neoform vessels after the radiation 5 4348,25 days was of $\mu \mathrm{m}^{2}$, while its group control presented an area of $1971,12 \mu \mathrm{m}^{2}$, in a sample of derma of 0,25 $\mathrm{cm}^{2}$. In 1988 Kirsch in a ultra-structural study with laser irradiation of the type Carbon Dioxide $\left(\mathrm{CO}_{2}\right)$ in the collagen of derma and the tendons, it told that this type of radiation would act in the shrinking of the collagen fiber, contributing, at least in part, for the retraction of the wounds, fact this that took in them to use prompt application. The comment of the two extremities of the wound (radiated and the control) for comparison ends denote of the fact of that, beyond the point reached for the radiation, the energy of the laser is absorbed only by a fine adjacent fabric layer, as the works told for Mester, that already in 1985 it affirmed that the entire ulcer would not total need to be radiated to get the stimulation, beyond what the penetration power does not exceed nineteen millimeters of derma. We observe in the two groups and the B and its respective controls in 20 day of after-debridement, the presence of elements of the cicatricial process (fibroblasts and vases), however being more evident in the radiated groups. No longer last day of therapy with laser, the groups and the B showed to greater structural organization when comparative to the group it has controlled, with fibroblasts, fibrocysit and collagen staple fibers, orienting itself parallel to the epidermis. Some authors come searching the effectiveness of the therapeutically one with laser emission as ally in the process of tissue healing, as Rocha et al. (2007), Meireles et al. (2005) and
Carvalho et al. (2006) however still is scarce the data in human beings, mainly in relation the pressure ulcers. A bigger epithelial regeneration and rich neo-vascularization has been detached in literature as well as the increment in the fibroblastic proliferation and collagenization, much even so Hallmann et al. (1988) in contraposition to the studies above cited, it observed that the irradiation with the HeNe laser in the dose of $24.7 \mathrm{~mW} / \mathrm{cm}^{2}$, during five days consecutive in the time of exposition of 1 minute did not present significant alterations in culture of fibroblasts of skin human being. In our balances, the histological and morphometric analyses suggest effect favorable of the components of the cicatricial process (fibroblasts, collagenization), as well as increment in the vascularization, the groups radiated in relation to the groups have controlled. The Action stimulant of the microcirculation was observed by Schindl (1998) in carrying patients of diabetes, as well as the granulation fabric presence represented for fibrosis, vascular neo-formation and infiltrated inflammatory to mononuclear, they had been considered in publications of Dallan and Oliveira (2000) during inquiries in the heart of patients in the final phase of the coronary arterial illness submitted to the transmiocardic revascularization with Laser $\mathrm{CO}_{2}$. The vascular neo-formation and tissue granulation presence, if had detached in both the groups, not having significant differences in the two groups. Bosartra et al. (1984), had analyzed cultures of human fibroblasts radiated by the $\mathrm{NeHe}$ laser in 2 doses of $\mathrm{J} / \mathrm{cm}^{2}$ during twenty days and had gotten a significant increase in the multiplication of these cellular types. This exactly fibroblastic increment was argued by Bolton et al. (1995).

\section{CONCLUSION}

Although some works to point with respect to the preference of the use of lasers of the type infra-red ray in the processes of tissue repairing, believe that, depending on the level and the depth of the injury, it can perfectly be viable the use of lasers of wave lengths above of the visible one for the acceleration of the tissue reply. Although many works have boarded in extensive way the performance of the laser radiation in fabrics, still some questionings without answers exist. The mechanisms that are effectively responsible for the 
stimulation of the fibroblastic activity not yet total had been elucidated, as well as the excellent dose of laser therapy of low power for the stimulation of tissue regeneration. With the clarification of such mechanisms of action it will be possible to establish criteria concerning the real benefits of the laser therapy in pathology that need the cicatricial stimulation, as the wounds opened in diabetic patients and ulcers of pressure, optimizing the current therapies and minimizing each time more the invasive and aggressive procedures to the patients. In our experiment we could evidence a discrete increase of the vascularization of the injuries (UP) submitted to the treatment of laser in the patients radiated for the laser GaAs diode (Arsenate-Gallium), pulsed, wave length $904 \mathrm{~nm}$, power of peak of $20 \mathrm{~W}$, and density of 3 prompt radiating energy of $\mathrm{J} / \mathrm{cm}^{2}$. Histological or morphometric differences in the patients radiated during 15 days alternated in relation to the treated ones per five days consecutive had not been observed. The anti-inflammatory effect analyzed by the application of the laser irradiation makes in them to believe that, depending on the level and the depth of the injury it can perfectly be viable the use of lasers of wave lengths above of the visible one for the acceleration of the tissue reply.

\section{ACKNOWLEDGEMENTS}

Thanks for Prof. Dr. Nivaldo A. ParizottoUFSCAR and Prof. Dr. Nilberto R.F. NascimentoUECE.

\section{RESUMO}

Neste trabalho, analisamos as alterações clínicas e modificações histológicas em pacientes com úlceras de pressão não infectadas, submetidos à irradiação Laser AsGa (comprimento de onda 904 $\mathrm{nm}$, dose $3 \mathrm{~J} / \mathrm{cm}^{2}$, durante 1 minuto e aplicação pontual) durante 5 dias consecutivos e um segundo grupo irradiado durante 15 dias alternados. $\mathrm{Na}$ avaliação clínica após a irradiação laser observouse presença de exsudação, tecido de granulação e pontos de sangramento após o terceiro dia de irradiação. A análise morfológica e quantitativa computadorizada demonstrou que os submetidos à irradiação laser durante 15 dias a área ocupada pelos vasos foi de $4115922 \mu \mathrm{m}^{2}$, e nos irradiados durante 5 dias de $4348253 \mu \mathrm{m}^{2}$, ambos em uma área de $0,25 \mathrm{~cm}^{2}$ de derme. Os resultados obtidos sugerem que esta terapêutica foi eficaz como auxiliar nos processos de regeneração tecidual nos pacientes tratados na pesquisa.

Palavras-Chave: laser, regeneração tecidual, angiogênese

\section{REFERENCES}

Amaral, A. (2002), Trends in Biological Dosimetry: an Overview. Braz Arch Biol Tec., 45, 119-124.

Dallan, L. A. O.; Oliveira, S. A. (2000), Cirurgia de revascularização transmiocárdica a laser de $\mathrm{CO}_{2}$. Rev Bras Cir Card., 15, 89-104.

González R. P.; Leyva A.; Melo R. A. B.; Moreira R. D. M.; Pessoa C; Farias R. F.; Moraes M. O. (2000), Method for in vivo study of angiogenesis: induction of neovascularization in the rabbit cornea. Act Cirurg Bras., 15, 1-3.

Gyselle, C. S. M. (2005), Comparative analysis of the effectlaser GaAIAs of $660 \mathrm{~nm}+780 \mathrm{~nm}$ in the cicatrization of ulcers for burnings in back of diabetic and not-diabetic rats: histologic study. Salvador, p120

Kirsch, K. M. (1998), Ultrastructure of colagen thermally denatured by microsecond domain pulsed carbon dioxide laser. Arch Derm., 134, 1-10.

Mester, E.; Mester A. (1998), The biomedical effects of laser application. Lasers in Surg and Med., 5, 31-39.

Rocha, J.; Adeir, M.; Beatriz, J. V.; Luís, C. F. A.; Fernando, M. A. (2007), Effects of low-level laser therapy on the progress of wound healing in humans:the contribuition of in vitro and in vivo experimental studies. J Vasc Bras., 6, 257-265.

Schindl, A.; Schindl, M.; Schon, H.; Knobler, R.; Havelec, L.; Schindl, L. (1998), Low- intensity laser irradiation improves skin circulation in patients with diabetic microangiopathy. Diabetes Care, 21, 580584.

Silva T. H. A.; Butera, A. P.; Leal D. H. S.; Alves R. J. (2007), Angiogenesis inhibitors antitumor agents Pharmacophore models to anb3 antagonists. Rev Bras Cienc Farm., 43, 1-17.

Stainki, D. R.; Raiser, A. G.; Graca, D. L. (1998), Radiação laser AsGa na regeneração do nervo radial submetido à reparação cirúrgica secundária. Braz Journ Vet Res Anim Sci., 35, 37-40.

Received: August 20, 2008; Revised: September 02, 2008; Accepted: September 05, 2008. 